\title{
Mushroom diversity in Shaki district of Azerbaijan
}

Elgun H. Mustafabayli

Dilzara N. Aghayeva ${ }^{1}$

Institute of Botany, Azerbaijan National Academy of Sciences, Badamdar 40, Baku, AZ1004, Azerbaijan

Abstract: Mushroom diversity in Shaki district of Azerbaijan was studied during 2013-2018. Totally 346 specimens were collected and identified based on the morphologically main diagnostic features. Phenotypic characters, as well as microscopic features (size, shape, color of spores) were considered. In total 111 taxa (106 species, three forms and two variations) belonging to 67 genera, 32 families and 11 orders of Ascomycota and Basidiomycta were identified in view of the latest taxonomic and nomenclature changes. Two taxa Morchella esculenta var. rotunda and Suillus luteus f. albus represent new records for Azerbaijan. Ecological groups of mushrooms were reflected. Amanita fulva, A. pantherina, A. vaginata, Apioperdon pyriforme, Boletus edulis, B. reticulatus, Bovista plumbea, Caloboletus radicans, Cantharellus cibarius, C. subalbidus, Chlorophyllum rhacodes, Coprinopsis atramentaria, Hymenopellis radicata, Hypholoma fasciculare, Lactarius piperatus, Leccinum scabrum, Lepiota cristata, Lycoperdon umbrinum, Morchella esculenta, Mycena crocata, M. pura, Russula foetens, $R$. rosacea, Sarcoscypha coccinea, Suillus granulatus, S. luteus, Suillellus luridus and Tricholoma ustale were frequently found in the district. The rare species found in the studied area were Butyriboletus regius, Cortinarius triumphans, Clavariadelphus pistillaris, Crepidotus cesatii, Lactarius deliciosus, Morchella crassipes, Otidea onotica, Suillellus queletii and Tuber aestivum. Species variation was observed to increase along the elevation gradient, starting from the low mountain zone. Abundance of species decreases in the middle-upper mountain zone. Species distribution patterns along the elevation gradients are affected by mountain range peculiarities and climate warming. Numerous species have been recorded in more than one altitude. Use possibility of fungi is also elucidated.

Key Words: ecological groups, edible, fungi, macromycetes, poisonous, species

Accepted for publication: 15 May 2019

1E-mail: a_dilzara@yahoo.com

\section{INTRODUCTION}

Information of the first mushroom records (Polyporus officinalis (Vill.) Fr., Tuber album Bull., Tuber melanosporum Vittad., Morchella esculenta (L.) Pers.) in Azerbaijan was mentioned in the medieval manuscripts [Alakbarli, 2006]. Based on available literature the first fungal collections were made by foreign botanists and mycologists who visited Azerbaijan [Georgi, 1800; Kolenati 1858; Voronov 1922-1923]. But the recorded and reported information on mushrooms is scanty, only few published works about fungi reached us [Aghayeva, 2018]. Significant contribution towards studying mushrooms belongs to A. Sadiqov, who launched first investigations on diversity since $60 \mathrm{~s}$ of the last century. In the result of this effort a wide range of mushrooms were investigated in the country [Opred..., 1985; Sadiqov, 1968, 1972, 2007; Sadiqov, Aghayeva, 2016]. Currently, about 2300 specimens of more than 800 mushroom taxa, much of which were collected by him, are stored in the Herbarium of the Institute of Botany (BAK) of ANAS [Aghayeva, 2018]. The study of fungi of various regions is also carried out continuously in order to identify species diversity, as well as rare and endangered species of fungi of the country [A ğayeva, Sadıqov, 2009, 2014; Qənbərov və s., 2012; Sadiqov, 1968].

The Greater Caucasus is among the botanically most diverse regions worldwide. Shaki district is one of the largest regions of northwestern Azerbaijan, which is located along the southern Caucasus mountain range. The area is rich in coniferous and mixed deciduous forests, and dominated by oak, beech, birch and hornbeam. The territory of the district can be divided into several climatic zones. Soils and climate are favorable for the growth of wide range of mushrooms. Plant diversity of the area is well studied, taking into account the number of herbarium samples kept in the BAK, but information on mushroom diversity is insufficient.

Thus, the aim of present study was to investigate the diversity of mushrooms in Shaki district, determine the systematic composition considering the latest taxonomic and nomenclatural changes, reveal ecological groups and distribution of mushrooms along elevation gradients, detect rare and endangered species in the country and identify the possibility of their use. 


\section{MATERIAL AND METHODS}

During mycological surveys mushroom specimens were collected from different localities of Shaki district at 675-2010 m a.s.1. in 2013-2018. Collected specimens were air dried and deposited to the BAK. GPS coordinates of sampling localities were as follow: Galarsan-Gorarsan fortress walls (N 41 ${ }^{\circ} 15^{\prime} 48.57^{\prime \prime}$, E $47^{\circ} 13^{\prime} 40.43^{\prime \prime}, 1220 \pm 50-60 \mathrm{~m}$ a.s.1.); along the Gilehli, hazel-nut forest (N 41 ${ }^{\circ} 12^{\prime} 14.29^{\prime \prime}$, E 47 $12^{\prime} 40.01^{\prime \prime}$, 835$860 \mathrm{~m}$ a.s.1.); Mustafabey oak-beech, chestnut-beech

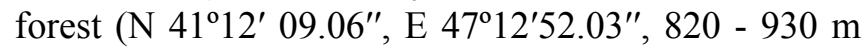
a.s.1.); Markhal resort complex (N 41 ${ }^{\circ} 14^{\prime} 34.85^{\prime \prime}$; E $47^{\circ}$ $\left.11^{\prime} 57.38^{\prime \prime}\right)$; Narıngala pine forest ( $41^{\circ} 15^{\prime} 32.60^{\prime \prime}$; E $47^{\circ} 13^{\prime} 5.60^{\prime \prime}, 1100 \pm 50-70 \mathrm{~m}$ a.s.1.); surroundings of Shaki Khans' Palace (N 41 ${ }^{\circ} 12^{\prime} 15.17^{\prime \prime}$, E $47^{\circ} 11^{\prime} 35.83^{\prime \prime}$, $770 \pm 50-70 \mathrm{~m}$ a.s.1.); in vicinity of Kungut village (N $41^{\circ} 9^{\prime} 45.72^{\prime \prime}$; E $47^{\circ} 18^{\prime} 48.05^{\prime \prime}, 880 \mathrm{~m}$ a.s.l.), in vicinity

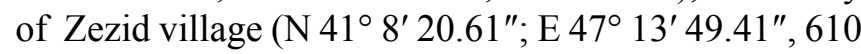
$\mathrm{m}$ a.s.1.); alley of martyrs in Shaki city (N $41^{\circ} 11^{\prime} 51.58^{\prime \prime}$ E $47^{\circ} 11^{\prime} 35.83^{\prime \prime}, 685 \mathrm{~m}$ a.s.1.).

Phenological features were examined by magnifying lens and micromorphological features were observed by the microscope (Vert. A1, Carl Zeiss, Axion Imager, Göttingen, Germany). Microscopic structures were mounted in the sterile water, statistics included of minimum 20 measurements. Both the size and shape of basidiospores were considered. The results are estimated as the average of measurements of each structure for each sample. Identification was carried out based on the available literature [Arora, 1986; Boddy et al., 2013; Bondartseva, 1998; Dermek, Pilát, 1969; Dudka, Wasser, 1987; Hills, 2009; Horak, 2005; Klofac, 2013; Ladurne, 2003; Moser, 1967, 1986; Muñoz, 2005; Opred..., 1985; Richard et al., 2015; Šutara, 2008; Wasser, 1980; Zerova et al., 1979]. Nomenclature updates and taxonomic arrangements were presented as in Index Fungorum Partnership and MycoBank Database.

\section{RESULTS AND DISCUSSION}

Taxonomic examination. In total 111 species (106 species, three forms and two variations) belonging to 67 genera, 32 families and 11 orders of Ascomycota and Basidiomycota (Table) were identified. Ascomycota is represented with nine species of five families and five genera, which were Helvella acetabulum (L.) Quél., $H$. atra J. König, H. lacunosa Afzel., Morchella esculenta, M. esculenta var. rotunda (Pers.) Secc., Otidea onotica (Pers.) Fuckel, Sarcoscypha coccinea (Gray) Boud. and Tuber aestivum (Wulfen) Spreng.
Basidiomycota was represented with 102 taxa of 27 families and 10 orders. Agaricales was dominant in number of families and genera. Agaricaceae included Agaricus bisporus (J.E.Lange) Imbach, Agrocybe praecox (Pers.) Fayod, Apioperdon pyriforme (Schaeff.) Vizzini, Bovista plumbea Pers., Chlorophyllum rhacodes (Vittad.) Vellinga, Echinoderma asperum (Pers.) Bon, Lepiota cristata (Bolton) P.Kumm., L. ignivolvata Boussent \& Joss, Leucoagaricus carneifolius (Gillet) M.M.Moser, Lycoperdon umbrinum Pers. and Macrolepiota fuliginosa (Barla) Bon. The family Amanitaceae was recorded with species of Amanita fulva Fr., A. pantherina (DC.) Krombh., A. rubescens Pers. and $A$. vaginata Bull. One species was identified from each Cortinariaceae, Fistulinaceae, Lyophyllaceae, Marasmiaceae, Omphalotaceae, Plutaceae families, which were Cortinarius triumphans Fr., Fistulina hepatica (Schaef.) With. Calocybe gambosa (Fr.) Singer, Marasmius capillaris Morgan, Mycetinis scorodonius (Fr.) A.W.Wilson \& Desjardin and Pluteus pellitus (Pers.) P.Kumm. respectively. Hymenogastraceae family included species of four genera, that were Galerina patagonica Singer, Ganoderma lucidum (Curtis) P.Karst., Hebeloma sinapizans (Paulet) Gillet. and Hypholoma fasciculare (Huds.) P.Kumm. The family Inocybaceae involved Crepidotus cesatii (Rabenh.) Sacc., Inocybe maculata Boud., I. rimosa (Bull.) P.Kumm. and Phaeomarasmius erinaceus (Fr.) Scherff. ex Romagn. Mycenaceae family comprised Hemimycena delectabilis (Peck) Singer, Mycena crocata (Schrad.) P.Kumm., M. haematopus (Pers.) P.Kumm., M. pura (Pers.) P.Kumm. The species Armillaria mellea (Vahl.) P. Kumm., Flammulina velutipes (Curtis) Singer and Hymenopellis radicata (Relhan) R.H.Petersen were recorded within Physalacriaceae. Coprinopsis atramentaria (Bull.) Redhead, Vilgalys \& Moncalvo, Coprinus comatus (O.F.Müll.) Pers. and C. picaceus (Bull) Gray. were included to the Psatyrellaceae. Clitocybe odora (Bull.) P.Kumm., Connopus acervatus (Fr.) K.W.Hugnes, Mather \& R.H.Petersen., Lepista nuda (Bull) Cooke, Tricholoma ustale (Fr.) P. Kumm were resided to the Tricholomataceae.

The order Boletales included families of Boletaceae, Gomphidiaceae and Suillaceae. Boletaceae was the richest among the families in number of genera and species and represented with species Boletus aereus Bull., B. edulis Bull., (B. edulis f. quercicola Vassilkov, B. edulis f. betulicola Vassilkov, B. edulis var. arenarius H.Engel, Krieglst. \& Dermek), B. purpureus Pers., B. reticulatus Schaeff., B. subtomentosus L., B. variipes 
Table. Taxonomic structure of mushrooms of Shaki district.

\begin{tabular}{|c|c|c|c|c|}
\hline Phylum & Orders & Families & Genera & $\begin{array}{l}\text { No } \\
\text { of spp. }\end{array}$ \\
\hline \multirow[t]{5}{*}{ Ascomycota } & Pezizales & Helvellaceae & Helvella $\mathrm{L}$. & 3 \\
\hline & & Morchellaceae & Morchella Dill. ex Pers. & 3 \\
\hline & & Pyronemataceaee & Otidea (Pers.) Bonord. & 1 \\
\hline & & Sarcoscyphaceae & Sarcoscypha (Fr.) Boud. & 1 \\
\hline & & Tuberacea & Tuber P. Micheli ex E.H. Wigg. & 1 \\
\hline \multirow[t]{27}{*}{ Basidiomycota } & Agaricales & Agaricaceae & $\begin{array}{l}\text { Agaricus L., Agrocybe Fayod, Apioperdon } \\
\text { (kreisel \& D.Krüger) Vizzini, Bovista Pers., } \\
\text { Chlorophyllum Massee, Echinoderma (Locq. } \\
\text { ex Bon) Bon, Lepiota (Pers.) Gray, } \\
\text { Leucoagaricus Locq. ex Singer, Lycoperdon } \\
\text { P.Micheli, Macrolepiota Singer }\end{array}$ & 11 \\
\hline & & Amanitaceae & Amanita Dill. ex Boehm. & 4 \\
\hline & & Cortinariaceae & Cortinarius (Pers.) Gray & 1 \\
\hline & & Fistulinaceae & Fistulina Bull. & 1 \\
\hline & & Hymenogastraceae & $\begin{array}{l}\text { Galerina Earl, Hebeloma (Fr.) P.Kumm., } \\
\text { Hypholoma (Fr.) P.Kumm. } \\
\text { Ganoderma P.Karst }\end{array}$ & 4 \\
\hline & & Inocybaceae & $\begin{array}{l}\text { Inocybe (Fr.) Fr., Phaeomarasmius Scherff., } \\
\text { Crepidotus (Fr.) Statue }\end{array}$ & 4 \\
\hline & & Lyophyllaceae & Calocybe Künher ex Donk & 1 \\
\hline & & Marasmiaceae & Marasmius Fr. & 1 \\
\hline & & Mycenaceae & Hemimycena Singer, Mycena Pers. Roussel & 4 \\
\hline & & Omphalotaceae & Mycetinis Earle & 1 \\
\hline & & Physalacriaceae & $\begin{array}{l}\text { Armillaria (Fr.) Staude, Flammulina } \\
\text { P.Karst., Hymenopellis R.H.Petersen }\end{array}$ & 3 \\
\hline & & Plutaceae & Pluteus Fr. & 1 \\
\hline & & Psathyrellaceae & Coprinopsis P.Karst., Coprinus Pers. & 3 \\
\hline & & Tricholomataceae & $\begin{array}{l}\text { Clitocybe (Fr.) Staude, Connopus R.H. } \\
\text { Petersen, Lepista (Fr.) W.G. Sm, } \\
\text { Tricholoma (Fr.) Staude }\end{array}$ & 4 \\
\hline & Boletales & Boletaceae & $\begin{array}{l}\text { Boletus Tourn., Butyriboletus D.Arora \& J.L. } \\
\text { Frank, Rheubarbariboletus Vizzini, Simonini } \\
\text { \& Gelardi, Rubroboletus Kuan Zhao \& Zhu } \\
\text { L.Yang, Caloboletus Vizzini, Imleria } \\
\text { Vizzini, Hemileccinum Šutara, Hortiboletus } \\
\text { Simonini, Vizzini \& Gelardi, Neoboletus } \\
\text { Gelardi, Simonini \& Vizzini, Leccinellum } \\
\text { Bresinsky \& Manfr. Binder, Leccinum Gray, } \\
\text { Suillellus Murrill, Xanthoconium Singer, } \\
\text { Xerocomus Quél }\end{array}$ & 27 \\
\hline & & Gomphidiaceae & Gomphidius Fr. & 1 \\
\hline & & Suillaceae & Suillus P. Micheli & 4 \\
\hline & Cantharellales & Cantharellaceae & Cantharellus Adans. ex Fr. & 2 \\
\hline & Geastrales & Geastraceae & Geastrum Pers. & 1 \\
\hline & Gomphales & Clavariadelphaceae & Clavariadelphus Donk & 1 \\
\hline & & Gomphaceae & Ramaria Holmsk. & 1 \\
\hline & Phallales & Phallaceae & Phallus Junius ex L. & 1 \\
\hline & Polyporales & Polyporaceae & $\begin{array}{l}\text { Cerioporus Quél., Lentinus Fr., Polyporus P. } \\
\text { Micheli ex Adans. }\end{array}$ & 5 \\
\hline & Russulales & Auriscalpiaceae & Auriscalpium Gray & 1 \\
\hline & & Russulaceae & Lactarius Pers. Russula Pers. & 13 \\
\hline & Thelaporales & Bankeraceae & Hydnellum P. Karst. & 1 \\
\hline & Tremellales & Tremellaceae & Tremella Pers. & 1 \\
\hline Total & 11 & 32 & 67 & 111 \\
\hline
\end{tabular}


Peck, Butyriboletus appendiculatus (Schaeff.) D.Arora \& J.L.Frank, B. regius (Krombh) D.Arora \& J.L.Frank, Caloboletus radicans (Pers.) Vizzini, Hemileccinum depilatum (Redeuilh) Šutara, Hortiboletus rubellus (Krombh) Simonini, Vizzini \& Gelardi, Imleria badia (Fr.) Vizzini, Leccinellum griseum (Quél.) Bresinsky \& Manfr. Binder, Leccinum crocipodium (Letell.) Watling, L. scabrum (Bull.) Gray., Neoboletus erythropus (Pers.) C.Hahu, Rheubarbariboletus armeniacus (Quél.) Vizzini, Simonini \& Gelardi, Rubroboletus legaliae (Pilát \& Dermek) Della Magg. \& Trassin., R. lupinus (Fr.) Costanzo \& Gelardi, Simonini \& Vizzini, $R$. satanas (Lenz) Kuan Zhao \& Zhu L.Yang, Suillellus luridus (Schaeff.) Murrill, S. queletii (Schulzer) Vizzini, Simonini \& Gelardi, Xanthoconium separans (Pect) Halling \& Both and Xerocomus chrysenteron (Bull.) Quél. The family Gomphidiaceae covered species Gomphidius roseus (Fr.) Fr. and five taxa of the genus Suillus (S. collinitus (Fr.) Kuntze, S. granulatus (L.) Roussel, S. luteus (L.) Roussel., S. luteus f. albus Wasser \& Soldatova).

The order Cantherellales included Cantharellus cibarius Fr. and C. subalbidus A.H.Sm. \& Morse of the family Cantharellaceae. Geastrum saccatum Fr. of the family Geastraceae, resided to the order Geastrales and Clavariadelphus pistillaris (L.) Donk of the family Clavariadelphaceae and Ramaria obtusissima (Peck) Corner of the family Gomphaceae were included to the order Gomphales. Only one species, Phallus ravenelii Berk. \& M.A.Curtis was identified belonging to the family Phallaceae of the order Phallales. Two Cerioporus species C. squamosus (Huds.) Quél., C. varius (Pers.) Zmitr. \& Kovalenko, one Lentinus species L. brumalis (Pers.) Zmitr. and two Polyporus species $P$. septosporus P.K.Buchanan \& Ryvarden and $P$. forquignoni Quél resided to Polyporaceae family of the order Polyporales. The order Russulales included two families, of which Auriscalpiaceae was indicated with Auriscalpium vulgare Gray and Russulaceae with Lactarius acris (Bolton) Gray, L. deliciosus (L.) Gray, L. piperatus (L.) Pers., L. volemus (Fr.) Fr., L. zonarius (Bull.)Fr., Russula albonigra (Krombh) Fr., R. delica Fr., $R$. foetens Pers., $R$. olivacea Pers., $R$. minutula Velen., $R$. rosacea (Pers.) Gray., $R$. turci Bres, $R$. virescens (Schaeff.) Fr. The order Thelaporales comprised only Hydnellum concrescens (Pers.) Banker from the family Bankeraceae. Tremella mesenterica Retz. was a single species belonging to the Tremellaceae of the order Tremellales. The taxon (Fig. 1) identified as-Morchella rotunda was synonimised within $M$. esculenta as $M$. esculenta var. rotunda [Richard et al., 2015]. This taxon and Suillus luteus f. albus are represent new records for the country [Klofac, 2013].

Seasonality of mushrooms. Much more of samples were

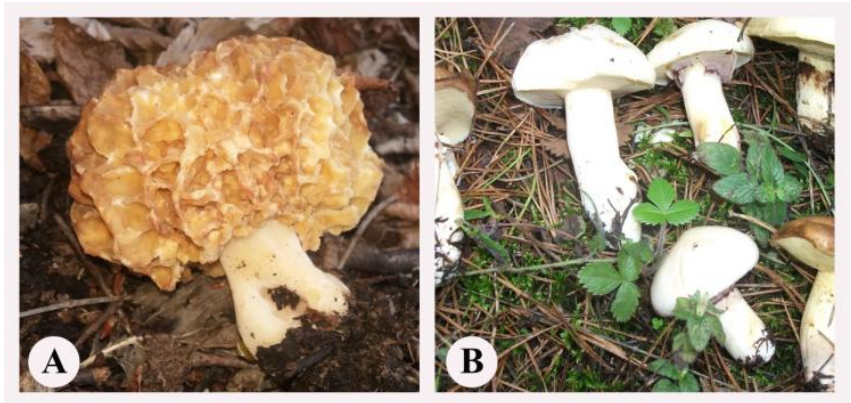

Figure 1. Two new taxa for Azerbaijan: (A) Morchella esculenta var. rotunda and (B) Suillus luteus f. albus

collected in the summer season (June, July, August) and included species of the genera Amanita, Apioperdon, Boletus, Butyriboletus, Caloboletus, Cantharellus, Cerioporus, Fistulina, Gomphidius, Hemileccinum, Hymenopellis, Hypholoma, Imleria, Lactarius, Leccinellum, Leccinum, Lycoperdon, Neoboletus, Phallus, Rheubarbariboletus, Rubroboletus, Russula, Suillellus and Xerocomus. Number of autum species were also significant and mainly belonged to the genera Agaricus, Apioperdon, Armillaria, Calocybe, Clavariadelphus, Clitocybe, Connopus, Coprinopsis, Coprinus, Cortinarius, Crepidotus, Echinoderma, Galerina, Gomphidius, Hebeloma, Hemimycena, Hydnellum, Imleria, Inocybe, Lactarius, Leccinum, Lepiota, Leucoagaricus, Lycoperdon, Macrolepiota, Mycena, Mycetinis, Neoboletus, Otidea, Pluteus, Ramaria, Russula, Suillus and Tricholoma. Species from the genus Flammulina, Gomphidius, Suillus and Tricholoma were found in the end of autumn and beginning of winter (December). Spring mushrooms were taxa belonging to the genera Auriscalpium, Boletus, Bovista, Helvella, Hymenopellis, Hypholoma, Lentinus, Morchella, Sarcoscypha, Xerocomus and Tuber.

Fungal distribution along elevation gradients. Specimens were collected in the low and middle mountain zone (500-1000 m a.s.1.), middle and upper mountain zone (800-1800 $\mathrm{m}$ a.s.1.), subalpine and alpine zone (1900-2400 $\mathrm{m}$ a.s.1.). The study showed that diversity of mushrooms changes along the elevational gradients. The low and middle mountain zone mushrooms included 86 taxa (82 species, 4 infraspecies) of the genera Agaricus, Amanita, Boletus, Bovista, Butyriboletus, Cantharellus, Caloboletus, 
Clavariadelphus, Coprinopsis, Coprinus, Ganoderma, Geastrum, Hemimycena, Hortiboletus, Hymenopellis, Hypholoma, Lactarius, Lentinus, Lepiota, Leccinellum, Leccinum, Lycoperdon, Macrolepiota, Morchella, Mycena, Mycetinis, Neoboletus, Phallus, Polyporus, Rubroboletus, Russula, Sarcoscypha, Suillellus, Suillus, Tremella, Tuber and Xerocomus (Fig. 2).

The higher number of taxa, about 35 species belon-

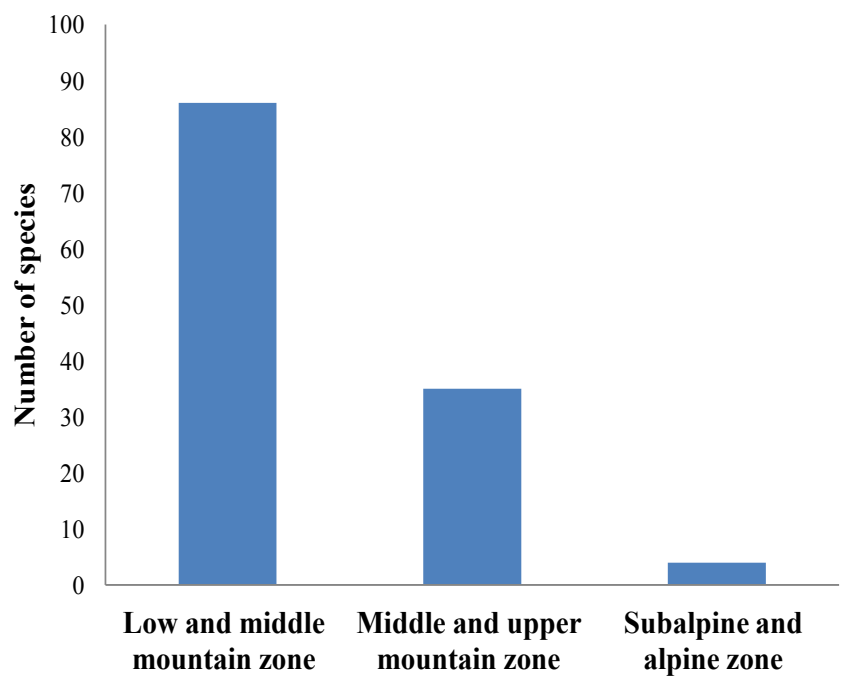

Figure 2. Distribution of mushrooms species along altitudinal zones of Shaki district.

ging to the genera Auriscalpium, Boletus, Butyriboletus, Calocybe, Cantharellus, Chlorophyllum, Clitocybe, Coprinus, Ganoderma, Gomphidius, Hymenopellis, Hypholoma, Lactarius, Lepiota, Lycoperdon, Marasmius, Morchella, Mycena, Mycetinis, Otidea, Polyporus, Russula, Sarcoscypha, Suillus, Tremella and Tricholoma were found in the middle and upper mountain zone.

Only three species and one infraspecies of the genera Amanita, Boletus and Sarcoscypha were recorded in the subalpine and alpine zone. Some species were recorded in more than one elevation zone. Species of the genera Amanita, Boletus and Sarcoscypha were collected in all three elevation zones, species of the genera Boletus, Cantharellus, Coprinus, Hypholoma, Lactarius, Lepiota, Morchella, Russula, Polyporus and Suillus in two elevation zones.

Ecological groups of mushrooms. Identified species can be differentiated as symbiotrophs, humus saprophytes and xylotrophs. Symbiotrophs was dominant among ecological groups with $53.16 \%$ of species belonging to the genera Amanita, Boletus, Butyriboletus Caloboletus, Clavariadelphus, Cortinarius, Hebeloma, Hemileccinum, Hortiboletus, Hydnellum, Imleria,
Inocybe, Lactarius, Leccinellum, Leccinum, Neoboletus, Rheubarbariboletus, Rubroboletus, Suillus, Suillellus, Russula, Tricholoma, Tuber, Xantoconium and Xerocomus. This group was followed by humus saprophytes which includes Agaricus bisporus, Bovista plumbea, Chlorophyllum rhacodes, Clitocybe odora, Coprinopsis atramentaria, Coprinus comatus, $C$. picaceus, Echinoderma asperum, Helvella acetabulum, $H$. atra, H. lacunosa, Leucoagaricus carneifolius, Lepiota cristata, Lepiota ignivolvata, Lepista nuda, Morchella crassipes, M. esculenta, Morchella esculenta var. rotunda, Mycena pura, Mycetinis scrodonius with $21.62 \%$ and xylotrophs that were Apioperdon pyriforme, Armillaria mellea, Auriscalpium vulgare, Cerioporus squamosus, C. varius, Connopus acervatus, Coprinopsis atramentaria, Crepidotus cesatii, Fistulina hepatica, Flammulina velutipes, Galerina patagonica, Ganoderma lucidum, Hemimycena delectabilis, Hymenopellis radicata, Hypholoma fasciculare, Inonotus obliquus, Lentinus brumalis, Leucoagaricus carneifolius, Lycoperdon umbrinum, Macrolepiota fuliginosa, Marasmius capillaries, Mycena crocata, M. haematopus, Mycetinis scrodonius, Otidea onotica, Phaeomarasmius erinaceus, Pluteus pellitus, Polyporus septosporus, P. forquignoni, Sarcoscypha coccinea, Tremella mesenterica) with $25.22 \%$ (Fig. 3).

Rare species. Three species among sampled collections

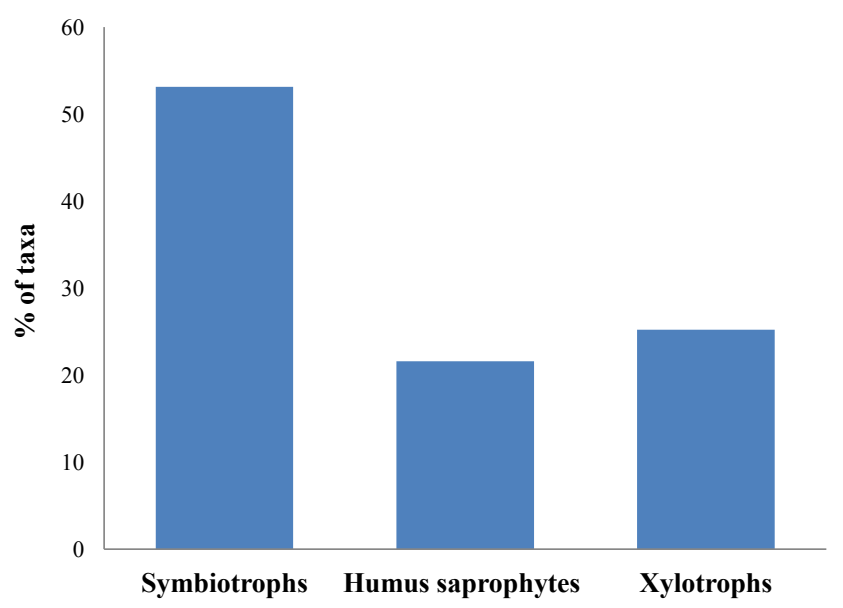

Figure 3. Ecological groups of mushroom species of Shaki district.

were rare for the territory of Azerbaijan. Species of Cortinarius triumphans, Crepidotus cesatii, Suillellus queletii were recorded as rare for Azerbaijan in the Key to agaric mushrooms of Transcaucasia by A.S.Sadiqov [Opred..., 1985]. Later Butyriboletus regius, Clavariadelphus pistillaris and Otidea onotica were included to the list of rare mushrooms for 
Europe [Grunert, Grunert 2002]. The Red Book of Azerbaijan [2013] includes 14 mushroom species of which Lactarius deliciosus, Morchella crassipes, Tuber aestivum were found in Shaki. Butriboletus regius, Cortinarius triumphans, Clavariadelphus pistillaris, Crepidotus cesatii, Lactarius deliciosus, Morchella crassipes, Otidea onotica, Suillellus queletii and Tuber aestivum were rare species in the studied area.

Usepossibility. Based on available literature all identified taxa were grouped as edible, conditional edible, not edible, poisonous, edibility not known (Fig.4) [Arora, 1986; Grunert, Grunert, 2002; Opred..., 1985; Sadıqov, 2007, 2009; Zerova et al., 1979]. Recorded edible taxa were Agaricus bisporus, Amanita rubescens, Apioperdon pyriforme, Armillaria mellea, Boletus aereus, $B$. edulis, f. quercicola, f. betulicola, var. arenarius, Boletus subtomentosus, B. reticulatus, B. variipes, Bovista plumbea, Butyriboletus appendiculatus, B. regius, Calocybe gambosa, Cantharellus cibarius, $C$. subalbidus, Cerioporus squamosus, Clitocybe odora, Coprinus comatus, Coprinopsis atramentaria, Fistulina hepatica, Flammulina velutipes, Gomphidius roseus, Helvella lacunose, Hymenopellis radicata, Imleria badia, Lactarius deliciosus, L. volemus, Leccinum crocipodium, Leccinellum griseum, L. scabrum, Lepista nuda, Lycoperdon umbrinum, Mycetinis scrodonius, Otidea onotica, Pluteus pellitus, Russula delica, $R$. olivacea, R. turci, R. virescens, Suillus granulatus, Suillus luteus f. albus, Tuber aestivum, Xanthoconium separans and Xerocomus chrysenteron according to the available literature [Arora D., 1986; Opred..., 1985; Sadiqov A. 2007]. Conditional edible are Helvella lacunosa, Lactarius acris, M. crassipes, M. esculenta, Neoboletus erythropus, Suillellus luridus, Suilellus queletii and Suillus luteus.

Amanita fulva, Amanita vaginata, Auriscalpium vulgare, Boletus purpureus, Caloboletus radicans, Clavariadelphus pistillaris, Coprinus picaceus, Ganoderma lucidum, Geastrum saccatum, Hydnellum concrescens, Lactarius piperatus, L. zonarius, Marasmius capillaries, Mycena crocata, M. haematopus, Russula albonigra, $R$. foetens, $R$. rosacea, Sarcoscypha coccinea, Tremella mesenterica, Tricholoma ustale mentioned not edible mushrooms in the above mentioned literature. Poisonous species were Amanita pantherina, Galerina patagonica, Hypholoma acutum, Hebeloma sinapizans, Inocybe maculata, I. rimosa, Mycena pura, Rubroboletus satanas.

Edibility not known were Agrocybe praecox, Cerioporus varius, Cortinarius triumphans, Crepidotus

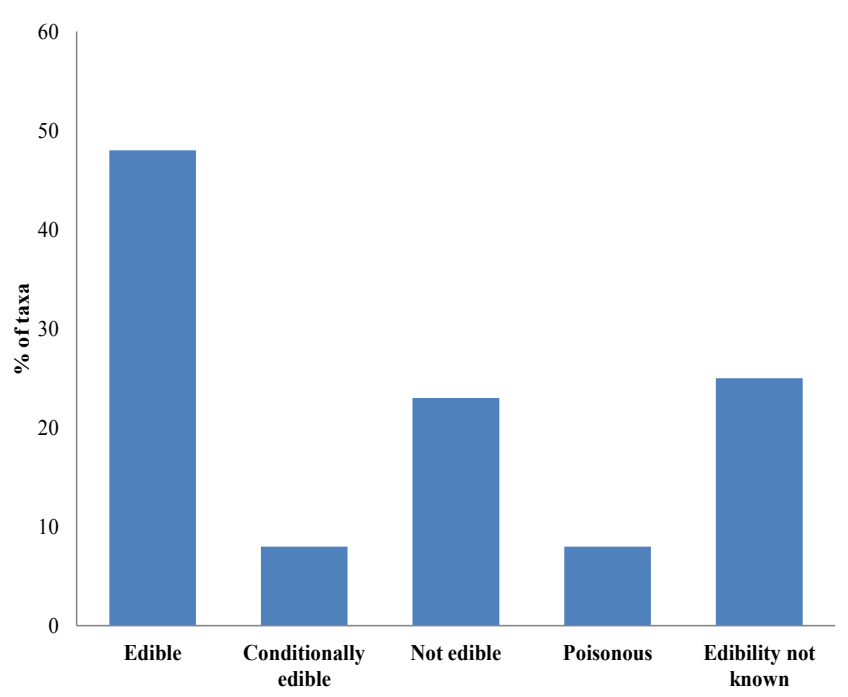

Figure 4. Nutritional significance of mushrooms species of Shaki district.

cesatii, Echinoderma asperum, Helvella acetabulum, H. atra, Hemimycena delectabilis, Hemileccinum depilatum, Hortiboletus rubellus, Lentinus brumalis, Lepiota ignivolvata, Leucoagaricus carneifolius, Morchella esculenta var. rotunda, Phaeomarasmius erinaceus, Phallus ravenelii, Polyporus septosporus, $P$. forquignoni, Ramaria obtusissima, Rheubarbariboletus armeniacus, Rubroboletus legaliae, R. lupinus, Russula minutula, Suillus collinitus and Suillus luteus f. albus.

In literature some species were classified into different categories. Morchella esculenta and $M$. crassipes were noted as high quality edible species by D. Arora [1986], but as conditionally edible by A. Sadiqov [2007]. Lepiota cristata was mentioned as possible poisonous by D. Arora [1986], but not poisonous or not edible mushroom by G. Grunert and B. Grunert [2002]. Also Chlorophyllum rhacodes were identified as edible in the book by D. Arora [1986], but conditionally edible in G. Grunert, B.Grunert [2002]. Amanita rubescens were described as conditionally edible in Zerova et al. [1979]. Neoboletus erythropus was mentioned as possible allergenic in D. Arora [1986], but highly edible in G. Grunert, B. Grunert [2002] and conditionally edible in Zerova et al. [1979].

Some species such as Helvella acetabulum, H. atra were included to the edibility not known group. Also possible edibility of Cortinarius triumphans, Crepidotus cesatii, Hemileccinum depilatum, Hemimycena delectabilis, Hortiboletus rubellus, Lepiota ignivolvata, Leucoagaricus carneifolius, Phaeomarasmius erinaceus, Ramaria obtusissima, Rheubarbariboletus armeniacus, Rubroboletus legaliae, R. lupinus, Russula 
minutula and Suillus collinitus were not mentioned in available literature.

\section{CONCLUSION}

Mushrooms are non-wood forest-product in forest ecosystem, data on their diversity and productivity is highly valuable. Fungi have significant effects on ecosystem processes and they are one of the main indicators of ecological disturbances. They are very sensitive to climate change that induces their fruiting, which could be also used as reliable indicator for monitoring the early climate change impacts [Alday et al., 2017; Boddy et al., 2013].

Nowadays fungal diversity' studies keep its importance. One of the challenges of mycological studies in the country is to continue search for fungal diversity in different ecosystems, establish rare and endangered species for the country; renew the list of identified edible, non-edible and poisonous species. Special interest is directed to the identification and use possibilities of mushrooms.

In this study the diversity of fungi of Shaki district was revealed. Fungal distribution along elevation zones was not significant and showed that most of fungi distributed in more than one altitude, but significant seasonal variation was observed and number of mushrooms in the summer season was obviously high. Fruiting season of some species is extended such as Lactarius deliciosus and Suillus granulatus. The most successful group among ecological ones was symbiotrophs, due to their role in nutrient circulation in mixed forests. Created datasets for Shaki district will help to effectively characterize spatial and temporal variability of mushrooms in the country.

\section{REFERENCES}

Aghayeva D.N. (2018) History of mycological investigation in Azerbaijan: classical approaches, modern initiatives and future challenges. First Intern. Sci. Conf. on History of Science and Science ...: Interdisciplinary studies. 29/30 October, p. 593-599.

Ağayeva D.N., Sadıqov A.S. (2014) Abşeronun mikobiotası. Bakı: Elm, 263 s. (in Azerbaijani)

Ağayeva D.N., Sadıqov A.S. (2009) Böyük Qafqaz və Talışdan toplanılmış müxtəlif ekoloji qruplara aid makromisetlər. AMEA Botanika Institutunun elmi asarlari, 29: 176-183 (in Azerbaijani)

Alakbarli F. (2006) Azerbaijan. Medieval manuscripts, history of medicine, medicinal plants. Baku: Nurlan. $125 \mathrm{p}$.
Alday J.G., Aragon J.M., Miguel S., Bonet J.A. (2017) Mushroom biomass and diversity are driven by different spatio-temporal scales along Mediterranean elevation gradients. Sci Rep, 7: 45824

doi: $10.1038 /$ srep45824

Arora D. (1986) Mushrooms demystified: A comprehensive guide to the fleshy fungi ( 2 nd ed.). Berkeley: Ten Speed Press, 959 p.

Boddy L., Büntgen U., Egli S., Gange A.C., Heegaard E., Kirk P.M., Mohammad A., Kauserud H. (2013) Climate variation effects on fungal fruiting. Fungal Biol, 30: 1-14.

Bondartseva M.A. (1998) Opredelitel' qribov Rossii. Poryadok Afillioforovie. SPb: Nauka, 2: 391p.

Dermek A., Pilát M. (1974) Poznávajne huby. Veda, Vydavatelstvo Slovenskej Akadémie Vied. $256 \mathrm{~s}$.

Dudka I.A., Wasser S.P. (1987) Qribi. Spravochnik mikoloqa i qribnika. Kiev: Naukova Dumka. 534 p. (in Russian)

Georgi J.T. (1800) Geographishch-physikalische und naturhistische Beschreibung des Russischen Reichs. Th. III. Bd. 5.

Grunert G., Grunert B. (2002) Qribi. Moskva: Astrel. $287 \mathrm{p}$.

Hills A.E. (2009) The genus Xerocomus. A personal view, with a key to the British species. Trans. Br. Mycol. Soc., 9 (3): 77-96.

Horac E. (2005) Rohrlinge und Blatterplize in Europa. München, $555 \mathrm{~s}$.

Index Fungorum Partnership: www.indexfungorum. com

Klofac W. (2013) A worldwide key to the genus Suillus. Österreichische Zeitschrift für Pilzkunde, 22: 211278.

Kolenati F.A. (1858) Die Bereisung Hocharmeniens und Elisabethopols, der Schekinschen Provinzund des Kasbek im Central - Kaukasus, Dresden: Kuntze, 6, $289 \mathrm{pp}$

Ladurne H., Simonini G. (2003) Fungi Europaei Xerocomus s.1. Italy: Edizioni Candusso, 527 p. (in Italian)

Moser M. (1967) Die Röhrlinge und ßlätterpilze (Agaricales). In: Kleine Kryptogamenflora. Jena: G. Fischer., ßd II b/2. 443 s. (in Germany)

Moser M. (1986) Guida alla determinazione dei fungi (Polyporales, Boletales, Agaricales, Russulales). Trento: Saturnia, 565 p. (in Germany)

MycoBank Database (Fungal databases, Nomenclature \& Species bank), International Mycological Association: www.mycobank.org 
Muñoz J.A. (2005) Fungi Europaei Boletus s.l. (excl. Xerocomus) Strobilomycetaceae, Gyroporaceae, Gyrodontaceae, Suillaceae, Boletaceae. Italy: Edizioni Candusso. 952 p. (in Italian)

Opredelitel' aqarikalnykh qribov Zakavkaz'ya (1985) Ed. I.G. Nakhusrishvili. Tibilisi: Meseniereba, 264 p. (in Russian)

Pilát A. (1969) Houby Československa ve svém životnim prostředi. Praha: Academia Nakladatelstvǐ Československé Academie Véd. 267 s. (in Czech)

Qənbərov X.Q., Ağayeva S.A., Sadiqov A.S. (2012) Talış meşələrinin mikoriza əmələ gətirən bazidili göbələkləri. Bakı: Elm., 178 s. (in Azerbaijani)

Red Book of Azerbaijan Republic. Rare and endangered plant and fungi species (2013) Second edition. Baku: Sharq-Qarb, $670 \mathrm{p}$.

Richard F., Bellanger J.M., Clowez P., Hansen K., O’Donnell K., Urban A., Sauve M., Courtecuisse R., Moreau P.A. (2015) True morels (Morchella, Pezizales) of Europe and North America: evolutionary relationships inferred from multilocus data and a unified taxonomy. Mycologia, 107(2): 359-382.

Sadiqov A.S. (1968) Shlyapochnie qribi Lenkoranskoy zoni Azerbaidjanskoy SSR. Avtoref. diss. kand. biol. nauk. Baku, 17 s.

Sadiqov A.S. (1972) Noviye dlya Azerbaidjana agarikovye qribi. Izvestiya AN Azerbaidjanskoy SSR, ser. biol. nauk, 1: 32-36. (in Russian)

Sadiqov A.S. (2007) Azərbaycanın yeməli və zəhərli göbələkləri. Bakı: Elm. 109s. (in Azerbaijani)

Sadiqov A.S., Ağayeva D.N. (2016) Azərbaycan üçün yeni makromisetlor. AMEA-nın Xəbərlari, biol. vo tibb elmlari, 71(2): 43-49. (in Azerbaijani)

Sutara J. (2008) Xerocomus s.l. in the light of the present state of knowledge. Czech Mycol, 60(1): 29-62.

Voronov Yu.N. (1922-1923) Trudy Tbilisskoqo botanicheskoqo sada. Tiflis: Tipoqrafiya Poliqrafotdela V.S.N.Kh.Q. 186 s.

Wasser S.P. (1980). Flora qribov Ukrainy. Aqarikovye qribi (Agaricales). Kuiv: Naukova dumka. 328 p. (in Ukarinian)

Zerova M.Ya., Sosin P.E., Rozhenko G.L. (1979) Viznachnik qribov Ukraini. Bazidiomiseti 5(2). Boletalni, strobilomisetaln1, trixolomataln1, entolomatalnı, rusulalnı, aqarikalnı, gasteromisetu. Kuiv: Naukova dumka. 564 c. (in Ukarinian)

\section{Azərbaycanın Şəki rayonunun papaqlı göbələk müxtəlifliyi}

\section{Elgün H. Mustafabəyli \\ Dilzarə N. A ğayeva}

AMEA Botanika Ínstitutu, Badamdar şossesi 40, Bakı, AZ1004, Azərbaycan

Azərbaycanın Şəki rayonunun göbələk müxtəlifliyi 2013-2018-ci illərdə tədqiq edilib. Ümumilikdə 346 göbələk nümunəsi toplanılıb və morfoloji xüsusiyyətlərinə görə təyinat aparılıb. Fenotipik xüsusiyətlər, həmçinin mikroskopik əlamətlər (ölçülər, forma və rəng) nəzərə alınmışdır. Son taksanomik və nomenklatur dəyişikliklərə əsasən Ascomycota və Basidiomycta şöbələrindən 67 cins, 32 fəsilə və 11 sıraya aid 111 taksa (106 növ, üç forma və iki variasiya) təyin edilmişdir. Morchella esculenta var. rotunda və Suillus luteus f. albus Azərbaycan üçün yeni taksonlardır. Göbələklərin ekoloji qrupları müəyyən edilmişdir. Amanita fulva, A. pantherina, A. vaginata, Apioperdon pyriforme, Boletus edulis, $B$. reticulatus, Bovista plumbea, Caloboletus radicans, Cantharellus cibarius, C. subalbidus, Chlorophyllum rhacodes, Coprinopsis atramentaria, Hymenopellis radicata, Hypholoma fasciculare, Lactarius piperatus, Leccinum scabrum, Lepiota cristata, Lycoperdon umbrinum, Morchella esculenta, Mycena crocata, M. pura, Russula foetens, R. rosacea, Sarcoscypha coccinea, Suillus granulatus, S. luteus, Suillellus luridus vo Tricholoma ustale rayon ərazisində tez-tez rast gəlinən növlərdir. Butyriboletus regius, Cortinarius triumphans, Clavariadelphus pistillaris, Crepidotus cesatii, Lactarius deliciosus, Morchella crassipes, Otidea onotica, Suillellus queletii və Tuber aestivum tədqiqat ərazisində nadir halda tap 1 lıb. Aşağı dağ qurşağından etibarən yüksəkliklər üzrə növ müxtəlifliyinin dəyişməsi qeyd edilmişdir. Orta-yuxarı dağ qurşaqlarından başlayaraq növlərin yayılması azalır. Göbələklərin yüksəkliklər üzrə paylanmasına relyefin xüsusiyyətləri və iqlimin təsiri müşahidə edilir. Bir sıra növlər birdən çox yüksəklikdə qeydə alınıb. Həmçinin göbələklərdən istifadə imkanları araşdırılıb. Açar sözlar: ekoloji qruplar, yemali, göbalak, makromisetlar, zaharli, növ 
Разнообразие шляпочных грибов в Шекинском районе Азербайджана

\section{Эльгюн Г. Мустафабейли}

\section{Дильзара Н. Агаева}

Институт Ботаники НАНА, Бадамдар 40, Баку, АZ1004,Азербайджан

Разнообразие шляпочных грибов в Шекинском районе Азербайджана изучено в 2013-2018 гг. Было собрано и идентифицировано 346 образцов на основе морфологических диагностических признаков. Учтены фенотипические свойства, а также микроскопические признаки (размеры, формы и цвет спор). Всего 111 таксонов (106 видов, три формы и две вариации), принадлежащих к 67 родам, 32 семействам и 11 порядкам Ascomycota и Basidiomycota, были определены с учетом последних таксономических и номенклатурных изменений. Morchella esculenta var. rotunda и Suillus luteus f. albus являются новыми таксонами для Азербайджана. Выявлены экологические группы шляпочных грибов. Amanita fulva, A. pantherina, A. vaginata, Boletus edulis, B. reticulates, Bovista plumbea, Caloboletus radicans,
Cantharellus cibarius, C. subalbidus, Chlorophyllum rhacodes, Coprinopsis atramentaria, Hymenopellis radicata, Hypholoma fasciculare, Lactarius piperatus, Leccinum scabrum, Lepiota cristata, Apioperdon pyriforme, Lycoperdon umbrinum, Morchella esculenta, Mycena crocata, M. pura, Russula foetens, R. rosacea, Sarcoscypha coccinea, Suillus granulatus, S. luteus и Tricholoma ustale часто встречаемые в районе виды. В изученном районе, были Butyriboletus regius, Cortinarius triumphans, Clavariadelphus pistillaris, Crepidotus cesatii, Lactarius deliciosus, Morchella crassipes, Otidea onotica, Suillellus queletii и Tuber aestivum обнаружены редко. Наблюдалась видовая изменчивость по высотам, начиная с низкогорной зоны. В средно-верхнем горном поясе численность видов снижается. На характер распределения видов влияют особенности горного хребта и потепление климата. Некоторые виды были зарегистрированы в более чем одной высотной зоне. Возможность использования грибов также выясняется.

Ключевые слова: экологические группы, съедобный, гриб, макромицеты, ядовитые, вид 